Taxonomy and systematics

\title{
Mites of the families Pygmephoridae and Neopygmephoridae (Acari: Pygmephoroidea) from soils in Mexico
}

\section{Ácaros de las familias Pygmephoridae y Neopygmephoridae (Acari: Pygmephoroidea) de suelos en México}

\author{
Ignacio M. Vázquez-Rojas ${ }^{\text {a,* }}$, Edith G. Estrada-Venegas ${ }^{\mathrm{b}}$, Mercedes G. López-Campos ${ }^{\text {a }}$ \\ ${ }^{a}$ Laboratorio de Acarología, Departamento de Biología Comparada, Facultad de Ciencias, Universidad Nacional Autónoma de México, Av. Universidad 3000, \\ Colonia Copilco, 04510 México, D.F., Mexico \\ ${ }^{\mathrm{b}}$ Entomología y Acarología, Colegio de Postgraduados, Carretera México-Texcoco, Km. 36.5 Montecillo, 56230 Texcoco, Estado de México, Mexico
}

Received 29 September 2014; accepted 11 March 2015

Available online 30 July 2015

\begin{abstract}
Mites of the families Pygmephoridae and Neopygmephoridae have been poorly studied in Mexico. Previous records from this group are: Acinogaster (A.) kansensis from Chiapas, A. (A.) marianae from Veracruz, Pygmephorus americanus from Mexico, some species of Siteroptes from Puebla and Pediculaster thailandensis from Quintana Roo. In this study we provide additional data, including specimens of Neopygmephoridae such as Kerdabania inconspicua, Bakerdania exigua, Pseudopygmephorus agarici, and P. shangaiensis; and of Pygmephoridae: Mahunkania secunda, Pediculaster ignotus and P. gracilis. Abundant specimens of Pediculaster ignotus were present in garlic crop soil.

All Rights Reserved () 2015 Universidad Nacional Autónoma de México, Instituto de Biología. This is an open access item distributed under the Creative Commons CC License BY-NC-ND 4.0.

Keywords: Prostigmata; Garlic crop; Organic soil; Phoretic mites

\section{Resumen}

Los ácaros de las familias Pygmephoridae y Neopygmephoridae de México han sido poco estudiados. Registros previos de este grupo son: Acinogaster (A.) kansensis de Chiapas, A. (A.) marianae de Veracruz, Pygmephorus americanus de México y especies de Siteroptes en muestras de Puebla, así como Pediculaster thailandensis del estado de Quintana Roo. En este estudio damos a conocer nuevos datos que incluyen a ejemplares de Neopygmephoridae como Kerdabania inconspicua, Bakerdania exigua, Pseudopygmephorus agarici and P. shangaiensis; también de la familia Pygmephoridae a Mahunkania secunda, Pediculaster ignotus y P. gracilis. La mayor abundancia de Pediculaster ignotus estuvo presente en suelos cultivados con ajo.

Derechos Reservados (C) 2015 Universidad Nacional Autónoma de México, Instituto de Biología. Este es un artículo de acceso abierto distribuido bajo los términos de la Licencia Creative Commons CC BY-NC-ND 4.0.
\end{abstract}

Palabras clave: Prostigmata; Cultivo de ajo; Suelo orgánico; Ácaros foréticos

\section{Introduction}

The family Pygmephoridae contains 30 genera and 350 species (Krantz \& Walter, 2009). These figures have

\footnotetext{
* Corresponding author.

E-mail address: mauro112003@yahoo.com.mx (I.M. Vázquez-Rojas).

Peer Review under the responsibility of Universidad Nacional Autónoma de México.
}

changed since the work by Kethley (1982), mainly due to recent reviews of this heterogeneous group. One of these changes is the re-establishment of the family Neopygmephoridae and the revision of generic characters to define them (Camerick, 2005; Khaustov, 2004). The most diverse genera of the families Pygmephoridae and Neopygmephoridae are Bakerdania Sasa, 1962 (about 100 species), Pygmephorus Kramer, 1877 (about 43 species) and Pediculaster Vitzthum, 1931 (about 95 species) (Camerick, 2010; Khaustov, 2004, 2008). 
Pygmephorid mites from Mexico cited by Hoffmann and López-Campos (2000) are Acinogaster (Acinogaster) kansensis Ross \& Cross, 1979 (USA, Mexico, Costa Rica, Panama, Ecuador, and Brazil) from Chiapas State; A. (A.) marianae Cross, 1965 (Mexico, Costa Rica, Panama, Ecuador, Guyana, and Trinidad) from Veracruz State; Pediculaster americanus (Banks, 1904) (USA, Mexico, and Haiti) from Mexico without more data. Species of Siteroptes Amerling, 1861 in soil samples from Puebla are also cited without any other data (Hoffmann \& López-Campos, 2000). Pediculaster thailandensis Camerick, 2005 on Chloropidae flies, from Playa del Carmen, Quintana Roo and from a rocky seashore on Tethinidae flies, from Tulum, Quintana Roo, Mexico, are the most recent records (Camerick, 2005).

We have been studying Prostigmata mites found in cultivated soils since 2005. Some results have already been published, particularly those about Ereynetidae from cultivated soils with a garlic (Allium sativum L.) crop in Guanajuato, Mexico (Vázquez-Rojas \& Estrada-Venegas, 2010). Here, we publish data on the families of Pygmephoridae and Neopygmephoridae found in garlic crop soil as well as, other natural, cultivated soils and compost. We consider the genera Mahunkania and Pediculaster as members of the family Pygmephoridae and the genera Bakerdania, Kerdabania and Pseudopygmephorus as members of the family Neopygmephoridae, following Khaustov (2004, 2009).

\section{Materials and methods}

All samples were collected by E. Estrada and A. Equihua from different parcels at the states of Guanajuato, Mexico, Veracruz and D. F. One kilogram of soil was processed by a Berlese Funnel by E. Estrada and her team along 1 year. The following arrangement of locality data was used: Guanajuato municipalities (in italics), parcel names and 2 letters as key of that name. Salamanca: El Fuerte (EF), El Tajo (ET), La Cuadrilla (LC), Pozo Félix (PF), San Isidro (SI) and San Juan (SJ); Comonfort: La Huerta (LH); Los Rodríguez: Mina 5 (M5); San Luis de La Paz: El Zorrillo (EZ) and El Nacimiento (EN). Same arrangement was used for other states and habitats. Compost samples at Texcoco (Montecillo), Mexico State (MTx); soil samples from Rio Tuxtla, Veracruz state (RTV); and soil samples from crops such as corn (Zea maiz L. 1753), pumpkin (Cucurbita pepo L. 1753), coriander (Coriandrum sativum L. 1753), and goosefoot (Chenopodium nuttalliae); from parcels P.J. Capultitla in Xochimilco, Distrito Federal (PJCX). A total of 167 specimens of Pygmephoridae and Neopygmephoridae were mounted on slides and studied; these will be deposited in the collection of the second author.

Drawings were made with a Zeiss compound microscope equipped with a camera lucida and then processed with Photoshop CS5. All measurements are expressed in $\mu \mathrm{m}$ and were made following the procedure by Camerick, 1996.

\section{Description}

Neopygmephoridae Cross, 1965

Pseudopygmephorus Cross, 1965

Type species: Pygmephorus tarsalis Hirst, 1921; Cross, 1965: 221

Pseudopygmephorus agarici Zou, Gao \& Ma, 1990: 373

(Figs. 1-6)

Phoretomorph females in soil of garlic crop in Guanajuato. 10, M5, 11/04/2002; 15, LH, 16/08/2001; 4, PF, 26/07/2000; 1, EN, 13/11/2001; 1, RTV, 01/10/2004; 1, ET, 17/07/2001; 1, PF, 15/05/2002. Soil 1, PJCX, 11/04/2007.

Distribution and habitats of the species described by Zou, Jian-Rong, and En-Pei (1990)

Holotype and allotype of $P$. agarici were found in mushroom compost as well as manure in Shangai, China. Paratypes were found in mushroom compost, compost being pasteurized and on straw in greenhouses (Zou et al., 1990).

Pseudopygmephorus agarici

Size intervals from 6 studied specimens. Body 81-131 wide; 195-320 long. Length of dorsal setae of 6 specimens: $v_{2} 8-10$, $s c_{2}$ 28-47, $c_{1}$ 23-30, $c_{2}$ 39-60, $d$ 21-40, e 17-33, f 24-44; $h_{1}$ 25-50, $h_{2}$ 16-20. Distances between dorsal setae: $v_{2}-v_{2} 21-27$, $s c_{2}-s c_{2}$ 17-24, $c_{1}-c_{1}$ 35-47, $c_{2}-c_{2}$ 80-111, $d-d$ 41-60, $f-f$ 42-61, e-e 56-78, $h_{1}-h_{1}$ 24-42, $h_{2}-h_{2}$ 58-82. Length of ventral setae: $1 a$ 20-28, $1 b$ 9-19, 2a 23-34, 2b 24-36, 3a 23-36, $3 b$ 24-34, 3c 12-24, 4a 23-30, 4b 29-41, 4c 21-30, ps 11-18, $p s_{2}$ 11-17, $p s_{3}$ 11-20. Length of tibiotarsus solenidia: $\omega_{1} 7-9$, $\omega_{2} 5-6, \varphi_{1} 3-5, \varphi_{2} 6-8$.

Other species of $P$. aphodii Khaustov, 2010 (Ukraine), have been found on dung beetles Aphodius fimetarius (L.), and P. smileyi Hill \& Deahl, 1978 (USA), on horse manure for commercial mushroom production (Hill \& Deahl, 1978; Khaustov, 2010).

Pseudopygmephorus shangaiensis Zou, Gao, \& Ma, 1990: 375 (Figs. 7-12)

Phoretomorph females collected in compost. 8, MTx, 19/07/2005.

\section{Distribution and habitat of the species described by Zou} et al. (1990)

Holotype, allotype and paratypes were found on manure and mushroom compost in Shangai, China (Zou et al., 1990).

Pseudopygmephorus shangaiensis

Size intervals from 5 specimens. Body, 89-126 wide; 170-310 long. Length of dorsal setae of 5 specimens: $v_{2} 8-10$, $s c_{2}$ 36-52, $c_{1}$ 22-30, $c_{2}$ 39-60, $d$ 22-30, e 14-31, f 23-31; $h_{1}$ 27-38, $h_{2}$ 13-21. Distances between dorsal setae: $v_{2}-v_{2} 24-32$, $s c_{2}-s c_{2}$ 18-24, $c_{1}-c_{1}$ 38-51, $c_{2}-c_{2}$ 80-119, $d-d$ 43-69, $f-f$ $44-68, e-e 47-86, h_{1}-h_{1} 22-35, h_{2}-h_{2} 54-83$. Length of ventral 

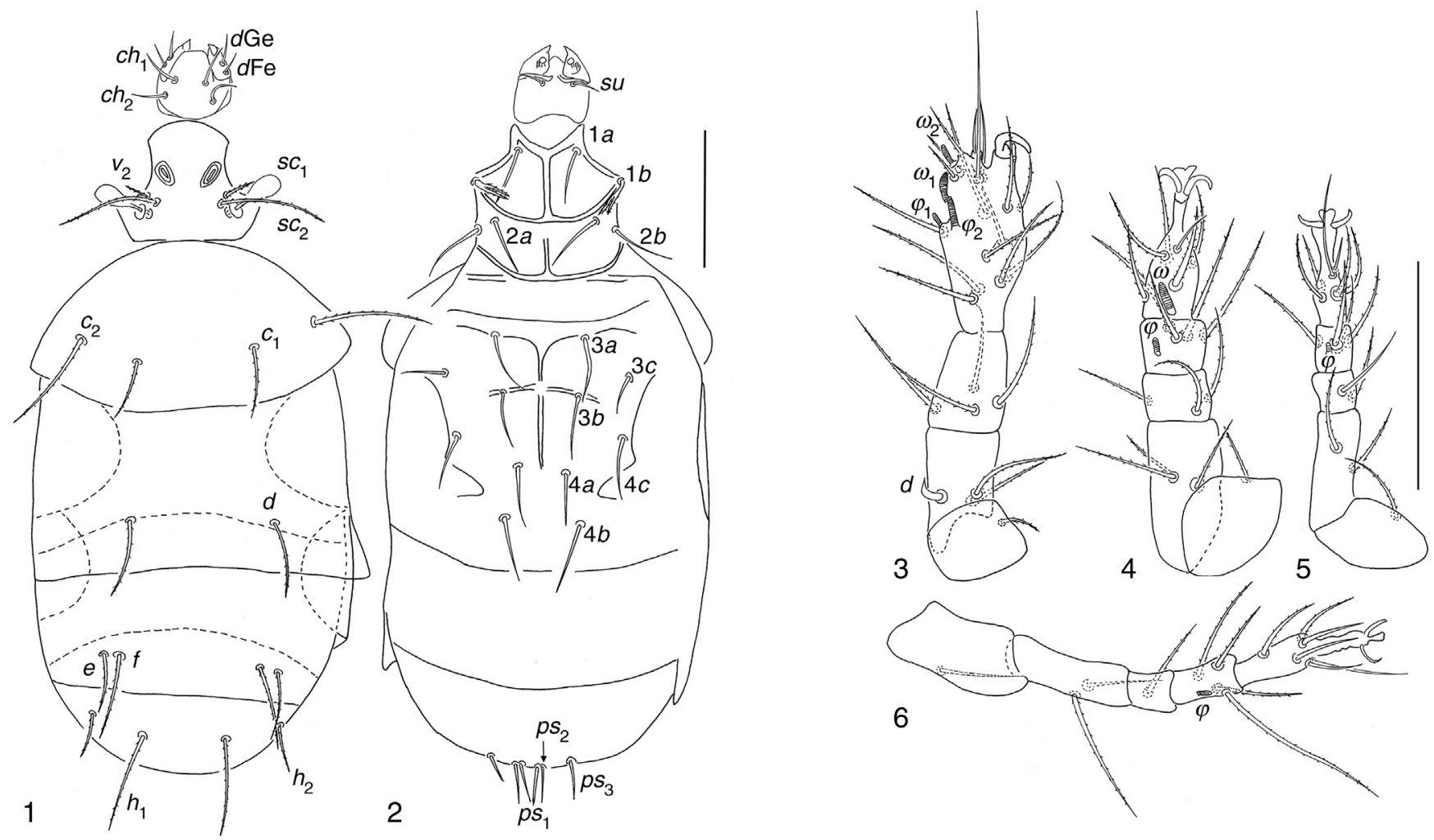

Figures 1-6. Pseudopygmephorus agarici. (1) Dorsal view; (2) ventral view; (3-6) legs I to IV. Scale bar $50 \mu \mathrm{m}$.
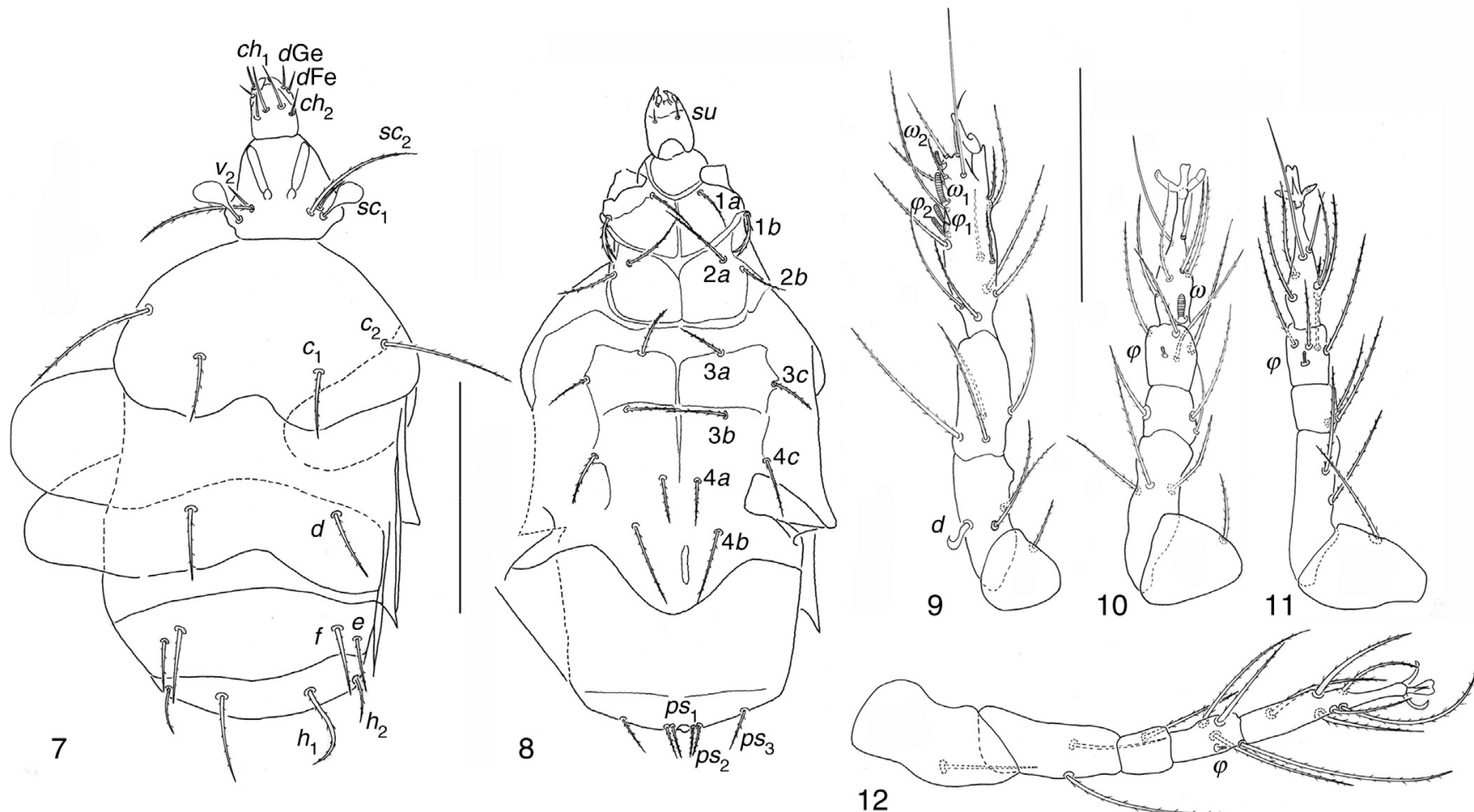

Figures 7-12. Pseudopygmephorus shangaiensis. (7) Dorsal view; (8) ventral view; (9-12) legs I to IV. Scale bar $50 \mu \mathrm{m}$. 
setae: $1 a$ 17-24, $1 b$ 13-20, $2 a$ 23-35, $2 b$ 15-24, 3a 15-29, $3 b$ 18-29, 3c 15-23, 4a 14-24, 4b 22-35, 4c 16-26, ps 1 10-18, ps 2 $10-17, p s_{3} 16-20$. Length of tibiotarsus solenidia: $\omega_{1} 7-9, \omega_{2}$ $3-5, \varphi_{1} 4-5, \varphi_{2} 6-7$.

\section{Kerdabania Khaustov, 2009}

Type species: Kerdabania magnifica, Khaustov, 2009: 171

Kerdabania inconspicua (Berlese, 1904) (Figs. 13-18)

Pigmephorus inconspicuus Berlese, 1904: 12

Scutacarus centriger Cooreman, 1951

Pygmephorus sellnicki Krczal, 1958: 69

Kerdabania inconspicuus (Berlese, 1904) Khaustov, 2009:183 comb. $n$.

Females in soil of garlic crop in Guanajuato State. 3, M5, 01/06/2002; 1, SI, 29/07/2002, 1; SI, 10/04/2002, 1, SI, 22/08/2002; 1, EN, 13/01/2001; 1, LC, 23/04/2003; 5, EZ, 29/07/2006. Females in cultivated soil in Xochimilco, D. F.: 2, PJCX, 23/05/2007, Coriandrum; 1, PJCX, 27/06/2007, corn; 1, PJCX, 11/04/2007, pumpkin; 1, PJCX, 28/03/2007, goosefoot.

\section{Distribution and habitat of the species renamed by \\ Khaustov (2009)}

The genus has worldwide distribution, except Antarctica. Forest litter and nests of small mammals and ants are known habitats. Phoresy unknown. K. inconspicua from Ukraine, vicinity of Poltava, soil under straw (Khaustov, 2009).

\section{Kerdabania inconspicua}

Body size interval, 232-282 wide, 107-116 long. Length of dorsal setae: $v_{2}$ 9-11, sc $242-47, c_{1} 38-42, c_{2} 42-48, d 33-40, e$ 11-22, $f$ 40-44, $h_{1}$ 35-41, $h_{2}$ 36-41. Distances between dorsal setae: $v_{2}-v_{2} 14-17, s c_{2}-s c_{2} 12-19, c_{1}-c_{1} 37-45, c_{2}-c_{2}$ 76-93, $d-d$ 43-58, f-f 43-60, e-e 57-72, $h_{1}-h_{1}$ 20-27, $h_{2}-h_{2}$ 43-55. Length of ventral setae: $1 a$ 15-20, $1 b$ 16-20, $2 a$ 24-28, $2 b$ 25-32, 3a 12-15, 3b 12-14, 3c 13-16, 4a 10-12, 4b 13-20, $4 c$ 14-19. Length of tibiotarsus solenidia: $\omega_{1} 6-9, \omega_{2} 4-6, \varphi_{1}$ 3-4, $\varphi_{2}$ 6-9.

\section{Bakerdania Sasa, 1961}

Type species: Pygmephorus cultratus Berlese, 1904; (1970)

Bakerdania exigua (Mahunka, 1969) (Figs. 19-24)

Neopygmephorus exiguus Mahunka, 1969: 533.

Bakerdania exiguus Mahunka, 1969; Mahunka, 1970: 348

Bakerdania exigua (Mahunka, 1969): Rack, 1972: 284.

Females in garlic crop soil in Guanajuato State. 2, EN, 16/01/2002; 1, PF, 13/02/2002; 1, 17/01/2002; 1, 14/03/2002; 1, SJ, 15/03/2002; 1, EF, 18/02/2002.

\section{Distribution and habitat of species by Mahunka (1970)}

Probably cosmopolitan, known from Europe and South America (Mahunka, 1970).

\section{Bakerdania exigua}

Body chaetotaxy agrees with B. exigua (Mahunka, 1969) except ventral setae $4 b$ (posesternals externals) which does not reach the vulva. Body 129-141 wide; 279-344 long. Length of dorsal setae: $v_{2} 7-8, s c_{2} 36-42, c_{1} 36-40, c_{2} 45-52, d 33-40, e$ 34-40, $f 44-50 ; h_{1}$ 53-62, $h_{2}$ 48-53. Distances between dorsal setae: $v_{2}-v_{2} 37-49, s c_{2}-s c_{2} 32-37, c_{1}-c_{1} 49-64, c_{2}-c_{2}$ 93-134, $d-d$ 26-31, f-f 69-86, e-e 87-104, $h_{1}-h_{1}$ 26-36, $h_{2}-h_{2}$ 56-65. Length of ventral setae: $1 a$ 24-32, $1 b$ 26-28, $2 a$ 30-36, $2 b$ 41-53, 3a 40-44, 3b 41-51, 3c 24-27, 4a 39-61, 4b 57-67, $4 c$ 23-38, $p s_{1}$ 12-13, $p s_{2}$ 7-9, $p s_{3}$ 11-13. Length of tibiotarsus solenidia: $\omega_{1} 17-22, \omega_{2} 8-9, \varphi_{1} 9-10, \varphi_{2} 9-10$.

Pygmephoridae Cross, 1965

Pediculaster Vitzthum, 1931

Type species: Pigmephorus mesembrinae Canestrini, 1880

Pediculaster ignotus Krczal, 1959 (Figs. 25-30)

Phoretomorph females in soil of garlic crop in Guanajuato State. 6, PF, 15/03/2002; 36, PF, 15/05/2002; 1, EZ, 29/07/2002; $1, \mathrm{EN}, 13 / 11 / 2001$.

Distribution and habitat of species by Rack (1965) and Camerick and Coetzee (1997)

The genus Pediculaster is cosmopolitan, with some species inhabit dung and fungi. Common habitat is cattle dung and compost; the mites are phoretic on Diptera (Camerick \& Coetzee, 1997). This genus is also known to inhabit soil, litter, mosses, and mammal droppings, mammal nests, plants and fruits (Camerick, 1996). Pediculaster ignotus was recorded from Hamburg-Langenhorn North, in organic material of 2-3 years of age (Rack, 1965).

Pediculaster ignotus

Characters in general agree with the genus and the species but $p s_{2}$ is different from other species in the genus because it is the shortest seta between $p s$ setae.

Pediculaster gracilis Camerick \& Ueckermann, 1995. (Figs. 31-36)

Phoretomorph females in soil of garlic crop in Guanajuato State. 2, EN, 13/12/2001; 1, EN, 13/09/2001; 2, EZ, 29/06/2002.

\section{Distribution and habitat of species described by Camerick and Ueckermann (1995)}

Type locality. Republic of South Africa, Johannesburg, Sandton, Innesfree Farm; habitat: horse and cow dung. Specimens also on Cynipidae (Hymenoptera) indeterminate (Camerick \& Ueckermann, 1995).

Pediculaster gracilis

Ventral side: Apodeme 3 not interrupted between setae $3 \mathrm{a}$.

Mahunkania Rack, 1972

Type species: Mahunkania hallensis Rack, 1972: 278

Mahunkania secunda Rack, 1975 (Figs. 37-42)

Phoretomorph females in soil of garlic crop in Guanajuato State. 3, PF, 15/05/2002. 

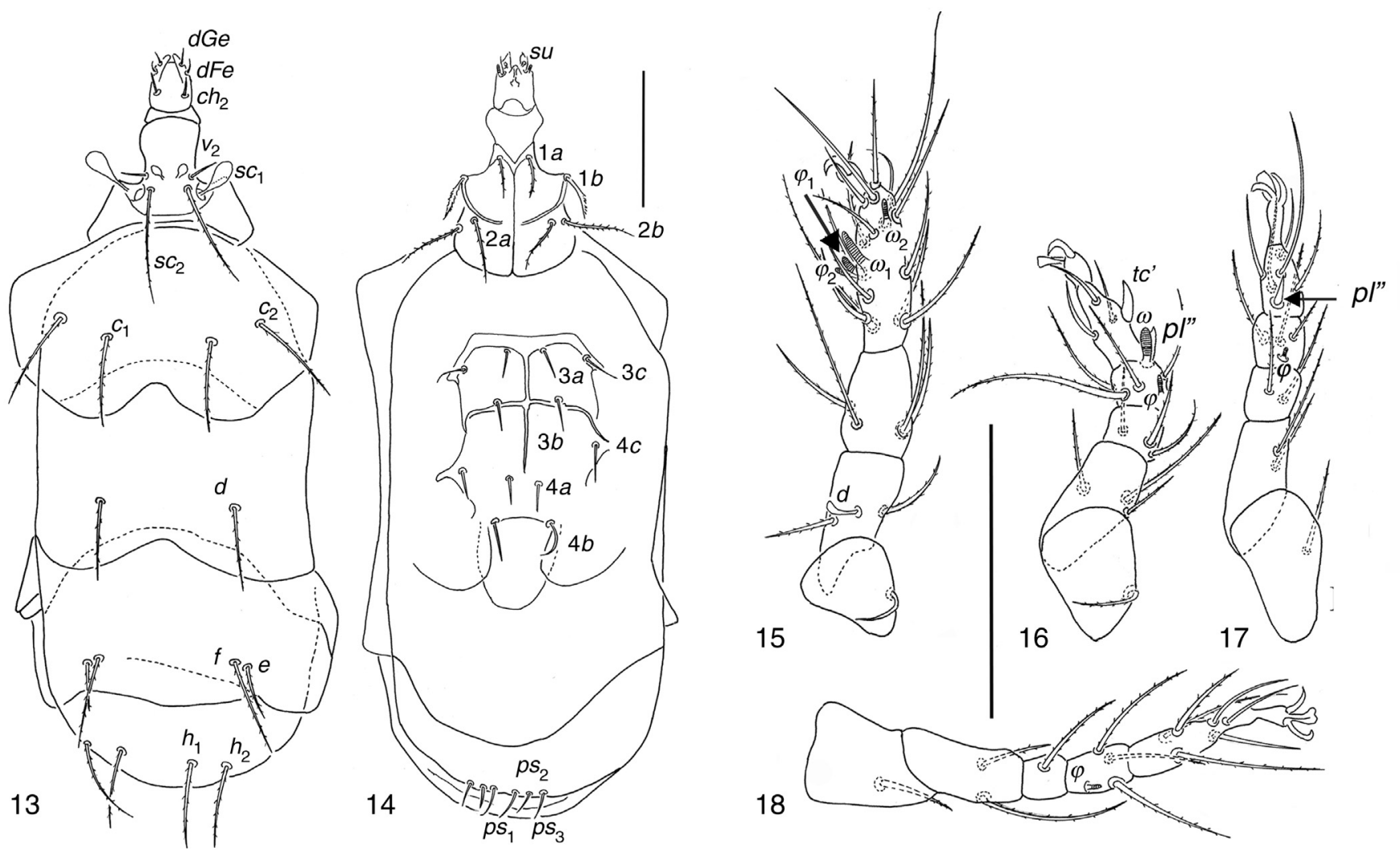

Figures 13-18. Kerdabania inconspicua. (13) Dorsal view; (14) ventral view; (15-18) legs I to IV. Scale bar $50 \mu \mathrm{m}$.
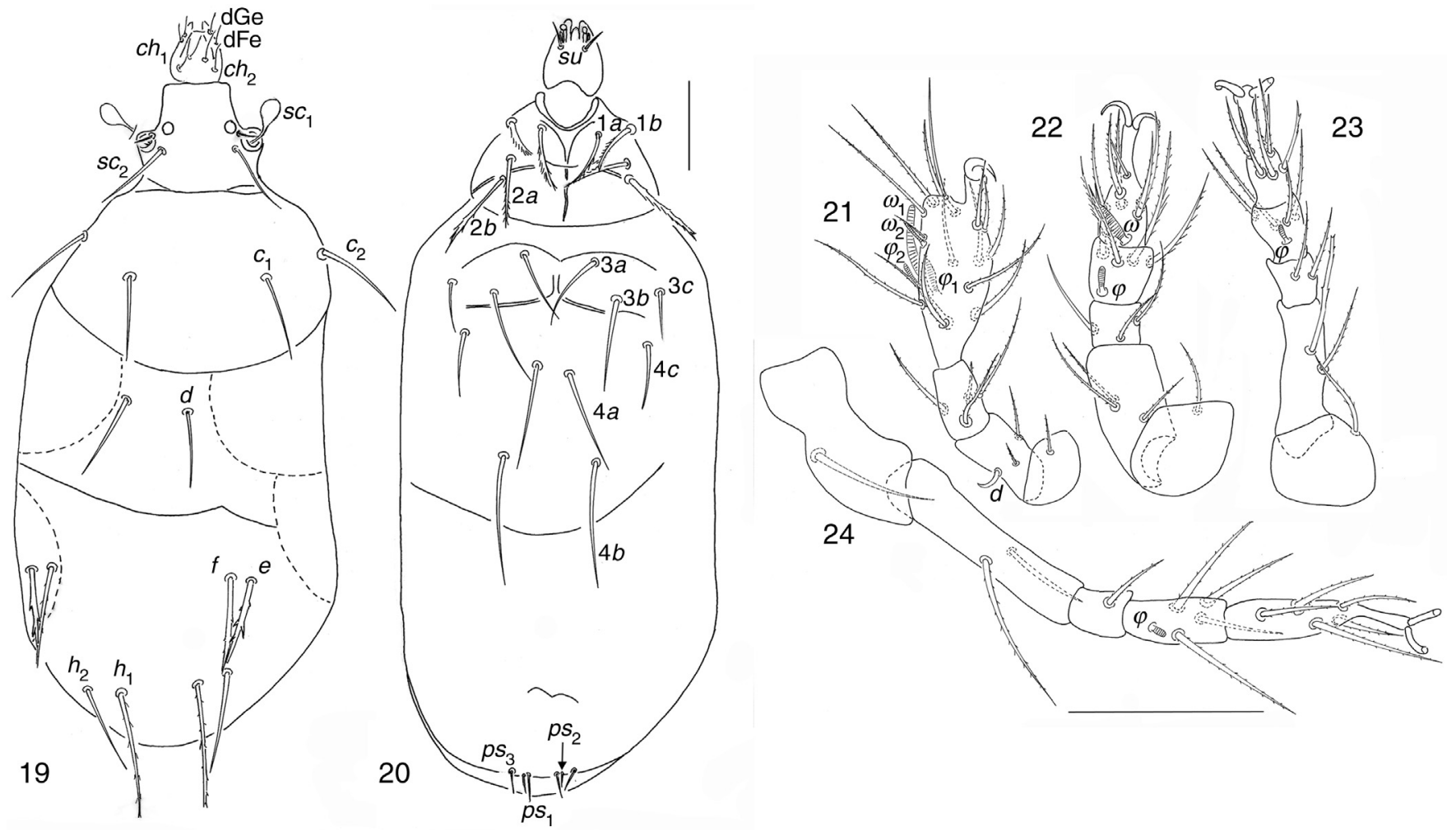

Figures 19-24. Bakerdania exigua. (19) Dorsal view; (20) ventral view; (21-24) legs I to IV. Scale bar $50 \mu \mathrm{m}$. 

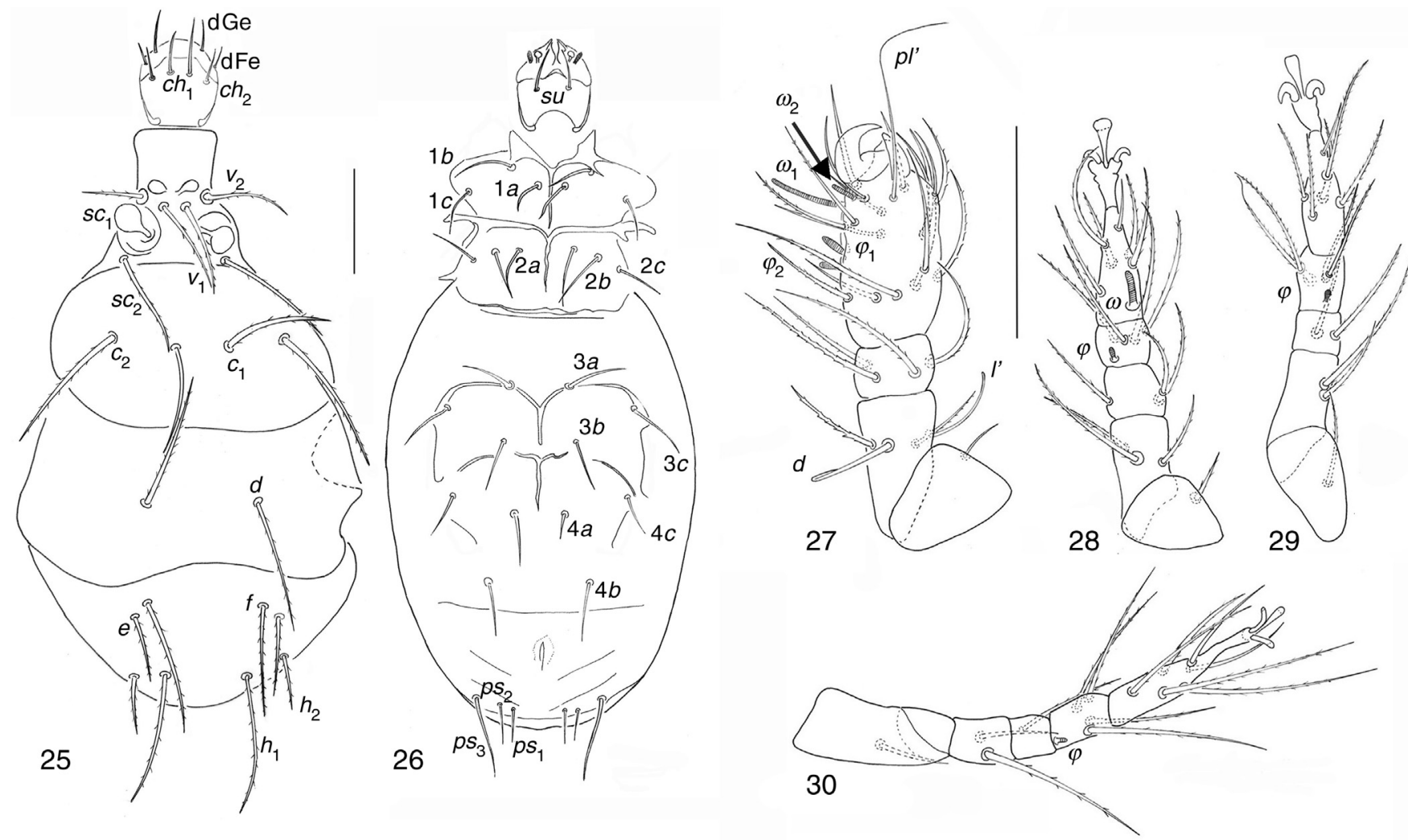

Figures 25-30. Pediculaster ignotus. (25) Dorsal view; (26) ventral view; (27-30) legs I to IV. Scale bar $50 \mu \mathrm{m}$.

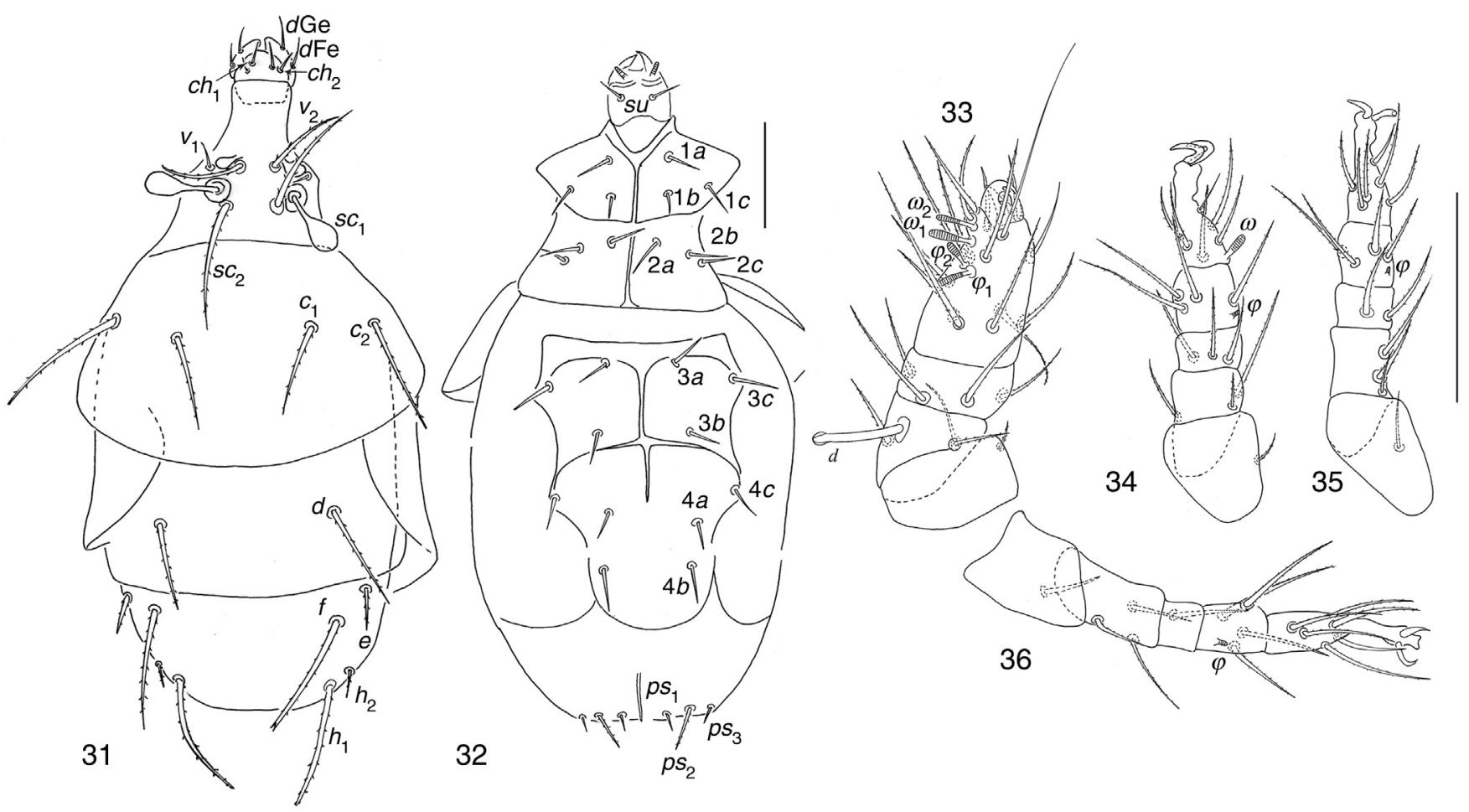

Figures 31-36. Pediculaster gracilis. (31) Dorsal view; (32) ventral view; (33-36) legs I to IV. Scale bar $50 \mu \mathrm{m}$. 

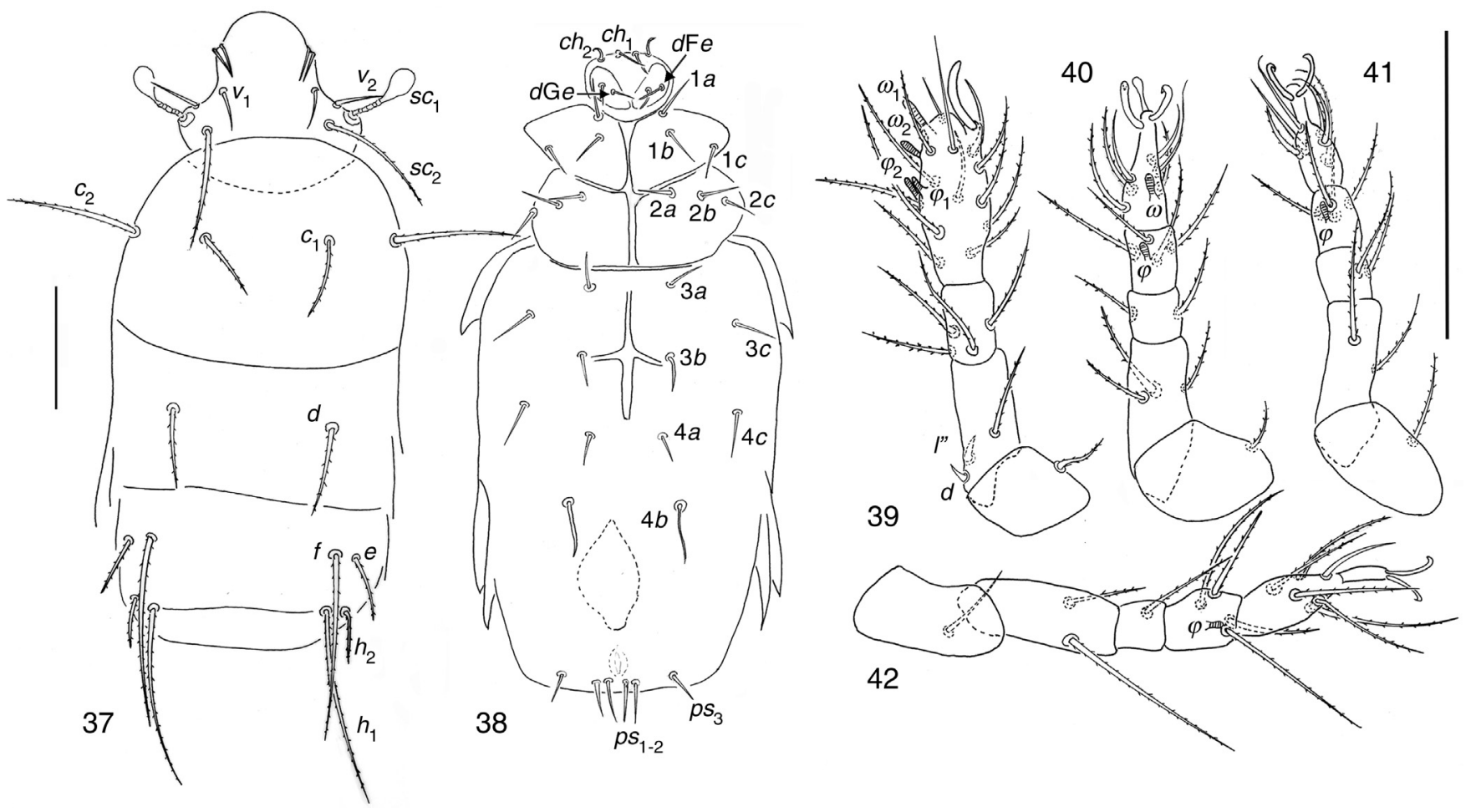

Figures 37-42. Mahunkania secunda. (37) Dorsal view; (38) ventral view; (39-42) legs I to IV. Scale bar $50 \mu \mathrm{m}$.

\section{Distribution and habitat of species described by Rack (1972)}

Mahunkania secunda was collected in Florida, USA from Fragaria sp. (Rack, 1972).

\section{Mahunkania secunda}

Studied specimens share with $M$. secunda the following characters after Kurosa (2002). Stigmata elongate-rectangular; prodorsal setae $v_{1}$ subequal in length to $v_{2}$; setae $e$ about $1 / 2$ as long as $f$; coxal setae $1 b$ directly posterior to $1 a$, not reaching apodeme 2 when directed backward; coxal $1 c$ neither longer nor thicker than $1 a$ and $1 b$; solenidia $\omega_{1}$ just apical in position, well apart from, and somewhat larger than $\omega_{2}$; seta $d$ on femur IV reaching apex of tibia; setae $d(3.35)$ and $l^{\prime \prime}$ (3.78) on femur I subequal in size.

\section{Discussion}

The biology and behavior of Pygmephorid mites have been poorly studied, and they usually have been found associated phoretically to insects but the soil relationships are not fully understood. These mites have been collected in soils with high levels of organic matter, feeding on fungi (Kurosa, 1999), in different ecosystems as soil crust in desert habitat (VillarrealRosas, Palacios-Vargas, \& Maya, 2014), termite nests (Wang, Powell, \& O'Connor, 2002) and Arctic deserts (Khaustov \& Makarova, 2005). Xochimilco soils are constantly improved with organic matter from the base of the lake, where the Chinampas zone is established. Garlic crop is usually associated with pathogenic fungi in the Guanajuato fields, so these conditions favor the Pygmephorid species. These mites are also vectors of fungal pathogens of plants and may feed preferentially on these phytopathogen fungi (Krantz \& Lindquist, 1979).

The genus Bakerdania is one of the largest genera in the Neopygmephoridae family, and includes about 100 species (Khaustov, 2008). They are found in all continents except Antarctica. These mites are piercing-sucking fungi with different feeding habits (Walter \& Proctor, 2013). They inhabit litter and eutrophic habitats, where they arrive by means of phoresy on insects (Kurosa, 1999).

The genus Pediculaster was abundant in samples, especially in garlic crop soil, with less abundant genera such as Bakerdania and Mahunkania, yet the latter remain very rare. Specimens of Pediculaster appear to be common in garlic crop soil, especially $P$. ignotus. With regard to this species, the difference in size of $p s_{2}$ is notorious with respect to other Pediculaster species; nevertheless, this seta is similar to $p s_{2}$ of $P$. ignotus shown by Rack (1965). In the drawing 14 (page 26) of Rack's paper the $p s_{2}$ is the shorter seta and the $p s_{3}$ is the largest, as was found in the specimens of this study. All specimens of $P$. ignotus are phoretic females; we believe that their insect hosts may be the visitors in or near the garlic crop. It is clearly necessary to collect insects related to the crop searching for mites to confirm this relationship (Camerick, 1996).

Pediculaster thailandensis was only found in compost. We assume that this species may be associated with some dipteran that dwells compost. As previously, the female phoretomorph leads us to believe that the presence of these mites is linked to the presence of host insects in the crop (Camerick, 2005).

All the records presented here are new for Mexico and for the substrata where they were collected. 


\section{Acknowledgements}

We thank Anne Camerick, University of Witwatersrand, Johannesburg, South Africa, for identifying specimens of Pediculaster and for submitting reprints on the subject. We thank also A. Khaustov from Tyumen State University, Tyumen, Russia, for helpful advice on the systematics of Neopygmephoridae and Heterostigmata, thanks for sending reprints of papers and help to the first author to identify species of Kerdabania and Bakerdania.

\section{References}

Camerick, A. M. (1996). Phoretic females of Pediculaster gautengensis sp. n (Acari: Pygmephoridae) associated with insects collected from dung in South Africa. Mittelungen Hamburg Zoologischen Museum Institut, 93, 161-170.

Camerick, A. M. (2005). Two new Pediculaster (Acari: Siteroptidae) species from Thailand and Mexico. Bulletin de la Societé Royale Belge d'Entomologie, 141, 63-71.

Camerick, A. M. (2010). Pediculaster-host relationships (Acari: Siteroptidae). Trends in Acarology. In Proceedings of the 12 international congress [2009] (pp. 337-342).

Camerick, A. M., \& Coetzee, S. H. (1997). The phoretic female of Pediculaster australis spec. nov (Acari: Pygmephroridae) from South Africa and new synonyms for P. morelliae. Bulletin de I'nstitut Royal des Sciences Naturelles de Belgique. Entomologie, 67, 33-43.

Camerick, A. M., \& Ueckermann, E. (1995). Pediculaster norrbomialis sp. n. and $P$. gracilis sp. n. (Acari Heterostigmata: Pygmephoridae) from South Africa, with notes on host and dung preference on their phoretic females. Mitteilungen aus dem Hamburgischen Zoologisschen Museum und Institut, 92, 73-86.

Cross, E. A. (1965). The generic relationships of the family Pyemotidae (Acarina: Trombidiformes). The University of Kansas Science Bulletin, 45, 29-275.

Hill, A., \& Deahl, K. (1978). A new species of Pseudopygmephorus (Acari: Pygmephoridae) associated with commercial mushroom production. In Proceedings of the Entomological Society of Washington, 80 (pp. 335-342).

Hoffmann, A., \& López-Campos, M. G. (2000). Biodiversidad de los ácaros de México. Mexico City: Conabio, UNAM

Kethley, J. (1982). Acariformes. In S. P. Parker (Ed.), Synopsis and classification of living organisms 2 (pp. 117-145). New York: McGraw Hill.

Khaustov, A. A. (2004). Mites of the family Neopygmephoridae Cross, 1965 stat. n. and their position in Heterostigmata. In Rossiyskaya Akademiya Nauk (Ed.), VIII Rossiyskoe Acarologicheskoe Soveshchanie (p. 137). SaintPetersburg: St. Petersburg Zoological Institute of RAS (in Russian).

Khaustov, A. A. (2008). Four new species of mites of the genus Bakerdania (Acari, Heterostigmata Kerdabania) gen. n., with four new species (Acari: Heterostigmata: Neopygmephoridae). Vestnick Zoologii, 42, 3-10.
Khaustov, A. A. (2009). A description of new genus Kerdabania gen. n., with four new species (Acari: Heterostigmata: Neopygmephoridae). Acarina, 17 , 171-188.

Khaustov, A. A. (2010). A new species of mite genus Pseudopygmephorus (Acari: Heterostigmata: Neopygmephoridae) associated with Aphodius fimetarius (Coleoptera: Scarabaeidae) from Crimea. Acarina, 18 , 261-264.

Khaustov, A. A., \& Makarova, O. L. (2005). Two new mite species of the genus Bakerdania (Acari, Heterostigmata, Pygmephoridae) from polar deserts of the Severnaya Zemlya archipelago. Entomological Review, 85, 141-146.

Krantz, G., \& Lindquist, E. E. (1979). Evolution of phytophagous mites (Acari). Annual Review of Entomology, 24, 121-158.

Krantz, G. W., \& Walter, D. E. (Eds.). (2009). A manual of acarology. Texas: Texas Tech University Press.

Kurosa, K. (1999). A new species of Bakerdania (Acari: Pygmephoridae) from the burying beetle Nicrophorus concolor (Coleoptera: Silphidae) in Japan. Journal of the Acarological Society of Japan, 8, 41-46.

Kurosa, K. (2002). A new species of the genus Mahunkania (Acari: Heterostigmata: Pygmephoridae) from Japan. Journal of the Acarological Society of Japan, 11, 91-99.

Mahunka, S. (1969). Sechs neue Milben-Arten aus der Familie Pyemotidae (Acari Trombidiformes). Acarologia, 11, 527-536.

Mahunka, S. (1970). Ergebnisse der zoologischen Forschungen von Dr Z. Kaszab in der Mongolei. 227. Acari: Pygmephoroidea. Annales Historico-Naturales Musei Nationalis Hungarici. Pars Zoologica, 62, 343-362.

Rack, G. (1965). Beschreibung von Pygmephorus ignotus Krczal 1959 und vier neuen Pyemotidae aus Hamburg (Acarina, Trombidiformes). A. Abhand und Verhandl der Naturwiss Vereins Hamburg, 9, 17-30.

Rack, G. (1972). Tarsonemina aus dem Saalkreis bei Halle (Acarina Trombidiformes). Entomologisches Mittelungen aus dem Zoologischen Museum Hamburg, 4, 277-286.

Rack, G. (1975). Three new species of Pygmephoroidea (Acarina: Tarsonemida) from Fragaria in Florida. The Florida Entomologist, 58, 231-238.

Vázquez-Rojas, I. M., \& Estrada-Venegas, E. G. (2010). Ereynetid mites (Tydeoidea: Ereynetidae) associated with garlic crops in Guanajuato, Mexico. In M. W. Sabelis, \& J. Bruin (Eds.), Trends in Acarology (pp. 207-210). Proceedings of the 12 International Congress, Amsterdam, 2006. New York: Springer.

Villarreal-Rosas, J., Palacios-Vargas, J. G., \& Maya, Y. (2014). Microarthropod communities related with biological soil crusts in a desert scrub in northwestern Mexico. Revista Mexicana de Biodiversidad, 85, 513-522.

Wang, L., Powell, J. L., \& O’Connor, B. (2002). Mites and nematodes associated with three subterranean termite species (Isoptera: Rhinotermitidae). Florida Entomologist, 85, 499-506.

Walter, D. E., \& Proctor, H. C. (2013). Mites: ecology, evolution and behavior. In Life at a microscale (2nd ed.). New York: Springer.

Zou, P., Jian-Rong, G., \& En-Pei, M. (1990). Two new species of Pseudopygmephorus associated with edible fungi from China (Acarina: Pygmephoridae). Acta Entomologica Sinica, 33, 373-379. 